\title{
Liver fibrogenesis in non-alcoholic steatohepatitis
}

\author{
Zhaolian Bian ${ }^{1,2}$ and Xiong Ma ${ }^{1,2}$ * \\ ${ }^{1}$ Division of Gastroenterology and Hepatology, Shanghai Institute of Digestive Disease, Renji Hospital, Shanghai Jiao-Tong University School of Medicine, \\ Shanghai, China \\ ${ }^{2}$ Key Laboratory of Gastroenterology and Hepatology, Ministry of Health, Shanghai Jiao-Tong University, Shanghai, China
}

\section{Edited by:}

Honglei Weng, University of

Heidelberg, Germany

Reviewed by:

Honglei Weng, University of

Heidelberg, Germany

Youming Li, Zhejiang University, China

*Correspondence:

Xiong Ma, Division of

Gastroenterology and Hepatology,

Shanghai Institute of Digestive

Disease, Renji Hospital, Shanghai

Jiao-Tong University School of

Medicine, 145 Shandong Middle

Road, Shanghai 200001 , China.

e-mail: maxiongmd@hotmail.com

\begin{abstract}
Non-alcoholic fatty liver disease (NAFLD) is emerging as one of the most common chronic liver diseases in developed western countries. Non-alcoholic steatohepatitis (NASH) is the most severe form of NAFLD, and can progress to more severe forms of liver disease, including fibrosis, cirrhosis, and even hepatocellular carcinoma. The activation of hepatic stellate cells plays a critical role in NASH-related fibrogenesis. Multiple factors, such as insulin resistance, oxidative stress, pro-inflammatory cytokines and adipokines, and innate immune responses, are known to contribute to the development of NASH-related fibrogenesis. Furthermore, these factors may share synergistic interactions, which could contribute to the process of liver fibrosis. Given the complex etiology of NASH, combined treatment regimes that target these different factors provide potential treatment strategies for NASH-related liver fibrosis.
\end{abstract}

Keywords: non-alcoholic fatty liver disease, hepatic stellate cell, hepatic fibrosis, cirrhosis

\section{INTRODUCTION}

Non-alcoholic fatty liver disease (NAFLD), affects one-third of adults and an increasing percentage of children in developed countries (Cohen et al., 2011). The disease spectrum of NAFLD includes simple steatosis, which is relatively benign, non-alcoholic steatohepatitis (NASH), NASH-related hepatic fibrosis, and cirrhosis (Jou et al., 2008). The disease begins with the aberrant accumulation of triglycerides in the liver, resulting in simple steatosis which is described as the benign form of NAFLD; most patients who develop steatosis are stable and further disease does not develop. However, some individuals progress to NASH, the severe form of NAFLD (Cohen et al., 2011). NASH is characterized by hepatocellular ballooning, lobular inflammation and hepatic fibrosis, besides steatosis (Brunt, 2004; Kleiner et al., 2005; Farrell and Larter, 2006). In NASH, 5-8\% patients will develop cirrhosis within 5 years, and up to $20 \%$ of patients with NASH progress into cirrhosis in the end (Krawczyk et al., 2010). NASH is considered to be the most important subcategory of NAFLD, and has the largest influence on the prognosis of NAFLD. Characterizing the mechanisms of hepatic fibrogenesis in NASH is critical for preventing disease progression and improving the prognosis of patients with NAFLD. Similar to liver fibrosis caused by hepatitis B virus (HBV) or hepatitis C virus (HCV) infection, the activation of hepatic stellate cells (HSCs) is critical in hepatic fibrogenesis. The specific factors involved in the pathogenesis of NAFLD, such as insulin resistance, oxidative stress, proinflammatory cytokines, adipocytokines, and the innate immune response, may also contribute to disease progression and the development of NASH-related hepatic fibrogenesis. Understanding NASH-related hepatic fibrogenesis is an important research area and will be valuable for identifying potential therapeutic targets to prevent the progression of NAFLD to NASH and more severe disease.

\section{ACTIVATION OF HEPATIC STELLATE CELLS}

Hepatic fibrosis, which is characterized by the excessive deposition of extracellular matrix (ECM) proteins, is considered to be a wound-healing process that results from a variety of chronic stimuli (Tsukada et al., 2006), such as viral hepatitis, NASH, or alcoholic liver disease. In adult NASH-related fibrosis, ECM is deposited primarily in the zone three perisinusoidal space of Disse, and then spreads to surround hepatocytes and thicken the space of Disse; forming characteristic "chicken-wire" fibrosis. Eventually, the pericentral fibrosis forms septa to isolate regenerating nodules (Law and Brunt, 2010; Pinzani, 2011).

The normal liver is composed of hepatocytes and nonparenchymal cells, which include kupffer cells, sinusoidal endothelial cells, and HSCs. HSCs are the major source of ECM in the fibrotic liver (Vera and Nieto, 2006). Normally, HSCs maintain a quiescent state and store a large amount of vitamin A. However, when the liver is injured HSCs undergo a phenotypic transition from a quiescent to activated phenotype. Accompanying this phenotypic transition, vitamin A is lost from the HSC, while the expression of smooth muscle $\alpha$-actin ( $\alpha$-SMA) is increased. After activation, the proliferation of HSCs is increased, and their gene expression profile is altered, especially the expression of type I and III collagen (Tsukada et al., 2006). In addition to the proliferation and secretion of collagen, the contraction of activated HSCs is greatly strengthened, which could result in portal hypertension in patients with hepatic fibrosis (Tsukada et al., 2006). In addition to the transforming growth factor (TGF) $-\beta$ signaling pathway, which is known to play major role in the activation of HSCs in liver fibrosis, many other signaling pathways are implicated in liver fibrosis in NAFLD, such as the hedgehog (Hh), PI3K/AKT, and JAK/STAT signaling pathways. Although the role of HSC activation in NAFLD has not been clarified completely, several studies have reported increased HSC activation in NASH (Kaji et al., 2011). 
The well-known role of HSCs in the pathogenesis of liver fibrosis suggests that they may play key role in NASH-related hepatic fibrosis, in which ECM deposition in the pericellular space forms a characteristic "chicken-wire" pattern (Marra et al., 2005).

\section{INSULIN RESISTANCE}

Insulin resistance plays key role in pathogenesis of NAFLD, especially in hepatic steatosis (Krawczyk et al., 2010). Genetic polymorphisms and acquired factors contribute to insulin resistance (Williams et al., 2011). Several studies have demonstrated that insulin resistance is associated with NAFLD (Chitturi et al., 2002; Bloom et al., 2008; Fracanzani et al., 2008). Serum levels of insulin and glucose are increased in either genetic or acquired insulin resistance. Insulin resistance also has effects on HSCs, which play a key role in liver fibrosis (Rombouts and Marra, 2010). Insulin itself promotes mitogenesis of HSCs, mainly through binding to insulin receptors and the receptors for insulin-like growth factorI. Glucose is also thought to significantly increase the expression of connective tissue growth factor, and slightly increase type I collagen expression in HSCs, both of which participate in NASHrelated fibrogenesis (Paradis et al., 2001). In humans, insulin resistance is closely associated with advanced stages of fibrosis in patients with NAFLD (Bugianesi et al., 2004). In contrast, insulin sensitizers, such as pioglitazone (Promrat et al., 2004; Sanyal et al., 2004; Aithal et al., 2008), rosiglitazone (Ratziu et al., 2008), and metformin (de Oliveira et al., 2008), can attenuate NASH-related hepatic fibrosis. These data suggest that insulin resistance plays an important role in NASH-related fibrogenesis.

\section{OXIDATIVE STRESS}

Oxidative stress reflects an imbalance between pro-oxidants and anti-oxidants with increased reactive oxygen species (ROS), (Chalasani et al., 2004) or decreased anti-oxidants (Koek et al., 2011). The generation of oxidative stress in NAFLD is associated with mitochondria, peroxisomes, and lipid peroxidation (Koek et al., 2011). In the context of NASH, it is known that oxidative stress induces the activation of HSCs (Guimaraes et al., 2006). For example, ROS can induce $\alpha$-SMA, type I collagen and MMP-2 expression in HSCs via the p38/MAPK signaling pathway (Ikeda et al., 2011; Li et al., 2011). Furthermore, CYP2E1, which plays a key role in the generation of oxidative stress in NAFLD, activate HSCs, and increase the secretion of type I collagen; moreover, antioxidants and CYP2E1 inhibitors could block these effects (Urtasun et al., 2008). NADPH, which is present in many kinds of cells in the liver, such as kupffer cells, hepatocytes, and HSCs, participates in liver fibrosis (De Minicis et al., 2006, 2010). This is linked to the renin-angiotensin system, which also plays an important role in liver fibrogenesis through the activation of NADPH oxidase (Bataller et al., 2005). More importantly, anti-oxidants, such as vitamin $\mathrm{E}$ and astaxanthin, can alleviate NASH-related fibrogenesis, which suggests oxidative stress plays a role in NASH-related fibrogenesis (Sanyal et al., 2004; McCarty, 2011).

\section{ADIPOKINES AND PRO-INFLAMMATORY CYTOKINES}

Adipocytokines, which specifically refer to adipose tissue-derived cytokines, are composed of various factors secreted primarily by adipocytes, as well as inflammatory cells, including macrophages, and other infiltrating monocytes (Marra and Bertolani, 2009). Examples of adipokines include adiponectin, leptin, resistin, tumor necrosis factor- $\alpha$ (TNF- $\alpha$ ), interleukin-6 (IL-6), and more recently discovered adipokines, such as visfatin, chemerin, vaspin (Kukla et al., 2011). It is thought that adipokines affect not only lipid metabolism, but also inflammatory and fibrotic processes in NAFLD (Marra and Bertolani, 2009).

Adiponectin is present in multimeric complexes in the plasma, and assembles into adiponectin trimers, hexamers, and 12- and 18-mers by means of its collagen domain (Rombouts and Marra, 2010). The effects of adiponectin are mediated by the two kinds of receptors, AdipoR2 and AdipoR1, which are primarily expressed in the liver and skeletal muscle, respectively (Marra et al., 2011). AdipoR2 expression was significantly decreased in rats fed a high-fat (HF) and cholesterol rich diet to induce inflammation and fibrosis in the liver, suggesting that AdipoR2 plays a major role in NAFLD (Matsunami et al., 2010). Several studies have also demonstrated that adiponectin has antifibrogenic effects in liver injury, and adiponectin deficiency exacerbates hepatic fibrosis induced by carbon tetrachloride $\left(\mathrm{CCl}_{4}\right)$ in mice. In vitro, adiponectin suppresses HSC proliferation and migration, and attenuates the gene expression stimulated by TGF- $\beta 1$ which is one of the most important pro-fibrogenic cytokines in liver injury induced by virus, NASH, and alcohol (Kamada et al., 2003). In adiponectin knockout mice fed a HF-diet, the pericellular fibrosis was more severe compared with WT mice (Asano et al., 2009). Similar results appeared in adiponectin knockout mice fed a choline-deficient L-amino aciddefined (CDAA) diet (Kamada et al., 2007). Furthermore, plasma adiponectin levels in patients with NASH are decreased, independent of the presence of obesity (Gastaldelli et al., 2010); however, another study found that adiponectin was elevated in patients with cirrhosis (Salman et al., 2010). Taken together, these data suggest that adiponectin is an important mediator of liver fibrosis.

Leptin is primarily secreted by adipocytes, but can also be produced by non-adipocyte cells, including HSCs (Zhang et al., 1994). The ob/ob mice, in which leptin is knocked out, developed less severe liver fibrosis induced by either $\mathrm{CCl} 4$ or thioacetamide (TAA), but when leptin levels were restored liver fibrosis was aggravated, suggesting that leptin is a potential pro-fibrogenic adipocytokine (Tsukada et al., 2006). Furthermore, it has been shown that leptin can promote the phenotypic transition of HSCs by activating the Hh pathway, altering gene expression programs that promote liver fibrosis. Meanwhile, the activation of the PI3K/AKT and JAK/STAT signaling pathways via binding to ObR (leptin receptor) contributes to the activation of the $\mathrm{Hh}$ pathway and mesenchymal gene expression, respectively (Choi et al., 2010). However, Cao et al. (2007) have reported that leptin could downregulate $M M P$ - 1 gene expression in LX-2 cell line via the synergistic actions of the JAK/STAT pathway and the JAK-mediated ERK1/2 and p38 pathways. Recent studies found that the serum level of leptin was elevated in NASH patients (Uygun et al., 2000), and levels of soluble leptin receptor in serum were positively correlated with the stage of fibrosis in NAFLD patients (Medici et al., 2010).

Data related to visfatin, chemerin, and vaspin in NASH-related liver fibrosis are limited. The expression of visfatin in the liver was significantly higher in NAFLD patients with liver fibrosis and was 
positively correlated with the stage of fibrosis (Kukla et al., 2010a). It has also been separately shown that serum levels of chemerin and vaspin were both increased in patients with NAFLD (Kukla et al., 2010b; Yilmaz et al., 2011a), and the level of chemerin was modestly associated with liver fibrosis (Sell et al., 2010; Yilmaz et al., 2011b). The effects of chemerin and vaspin on liver fibrosis in NAFLD need to be studied in order to better understand their importance in the pathogenesis of NASH.

TNF- $\alpha$ is considered an important pro-inflammatory cytokine produced predominantly by the immune cells in the liver in NASH. IL-6, a multifunctional cytokine, promote insulin resistance (Kim et al., 2004), protect hepatocytes in steatotic liver by restraining oxidative stress and mitochondrial dysfunction (Cressman et al., 1996; El-Assal et al., 2004). Jin et al. (2006) reported that shortterm IL-6 treatment protects mice from Fas-mediated liver injury and apoptosis, while result of long-term IL- 6 treatment is paradoxical. These cytokines are involved in the transformation of HSCs into myofibroblasts, which contribute to the progression of liver fibrosis. TNF- $\alpha$ affects HSCs via binding to the TNF receptor-1, which is required for HSC proliferation and increasing MMP-9 expression (Tarrats et al., 2011). Serum levels of IL-6 in patients with NASH is associated with liver fibrosis (Lemoine et al., 2009). Taken together, these data suggest cytokines may play roles in liver fibrosis in NAFLD, and may present as targets for the treatment of liver fibrosis.

\section{TOLL-LIKE RECEPTORS}

The multiple parallel hits hypothesis was proposed recently by Tilg and Moschen (2010) to explain the pathogenesis of NASH. This hypothesis states that various parallel factors, including gutderived and adipose tissue-derived factors contribute to the development of liver fibrosis in NAFLD. The endotoxin lipopolysaccharide (LPS), derived from bacteria cell walls in the gut is known to play a role in the development of liver inflammation and fibrosis (Day and James, 1998; Jou et al., 2008). LPS has its effect by binding to the pattern-recognition receptors, especially Toll-like receptor (TLR)-4, where it triggers multiple intracellular signaling pathways, and then amplifies and maintains the inflammatory and fibrogenic signals in the liver (Brun et al., 2005; Seki et al., 2007). In brief, LPS activates HSCs through binding to TLR4 on the cellular surface, this promotes HSC proliferation and collagen production. TLR9, another TLR, was reported to promote HSC activation and to upregulate collagen production in vitro (Watanabe et al., 2007). Recently, Miura et al. (2010) also showed that TLR9 knockout mice developed less steatohepatitis and liver fibrosis in a murine NAFLD model, through suppressing the IL- $1 \beta$ produced by kupffer cells.

\section{NATURAL KILLER T CELLS}

Natural killer T (NKT) cells, a subset of lymphocytes that secretes not only Th1-type cytokines such as interferon- $\gamma$, but also Th2type cytokines such as IL-4 (Hegde et al., 2010). Studies reported that the HF-diet mice induced NKT cell apoptosis in the liver, which resulted in the decrease of hepatic NKT cells (Li et al., 2005; Deng et al., 2009). Oral immune regulation may alleviate steatosis in ob/ob mice through increasing hepatic NKT cells (Elinav et al., 2006). However, the population of hepatic NKT cells in NAFLD patients is controversial. Kremer et al. (2010) reported that hepatic NKT cells were decreased in NASH patients, and was associated with worse degrees of steatosis grade. In contrast, Tajiri et al. (2009) found that NKT cells in the liver and peripheral blood was increased with increasing NAFLD activity score. Adler et al. (2011) reported that NKT cells in the liver and blood significantly increased in patients with moderate to severe steatosis. CD1d-knockout mice, lacking NK1.1+ T cells, developed minimal hepatic fibrosis following chronic TAA treatment, compared to wild type mice (Ishikawa et al., 2011). Recently, it was shown that activation of the Hh pathway lead to hepatic accumulation of NKT cells that may activate HSC cells, resulting in progression of liver fibrosis in NASH (Syn et al., 2010). These data suggest that NKT cells may play pivotal roles in pathogenesis of NAFLD, not only in inflammation and steatosis, but also in fibrosis.

\section{NUCLEAR RECEPTORS}

Nuclear receptors regulate the expression of genes via binding directly to DNA. Several nuclear receptors, such as retinoid acid receptors (RAR), retinoid $\mathrm{X}$ receptor (RXR), and peroxisome proliferator-activated receptors (PPARs), participate in the process of phenotypic transition from quiescent HSCs to activated myofibroblastic-like cells (Wagner et al., 2011).

PPARs also play a key role in HSC biology and fibrosis in NAFLD, especially PPAR $\gamma$ (De Minicis and Svegliati-Baroni, 2011). It is known than PPAR $\gamma$ plays a role in the maintenance of a quiescent HSC phenotype, and that PPAR $\gamma$ agonists suppress the fibrogenic potential of HSCs in vitro and in vivo; specifically, pioglitazone and rosiglitazone, two kinds of PPAR $\gamma$ agonists, have been shown to alleviate liver inflammation and fibrosis in murine NASH models (Polyzos et al., 2010; Nakagami et al., 2012). Furthermore, pioglitazone also decreased liver fibrosis in patients with NASH (Gastaldelli et al., 2010; Ratziu et al., 2010); though another study reported pioglitazone could decrease inflammation in liver, but did not affect liver fibrosis (Belfort et al., 2006).

The farnesoid X receptor (FXR), also known as the bile acid receptor, induces expression of the small heterodimer partner, which may induce PPAR $\gamma$ gene expression and then inhibit the activation of HSCs (Fiorucci et al., 2004; Renga et al., 2011). GW4064, an agonist of FXR, has been shown to inhibit the transdifferentiation of HSCs, and reduce their contractile response to endothelin-1. (Li et al., 2010) The liver X receptors (LXRs) are members of the metabolic nuclear receptor family that plays roles in the regulation of cholesterol absorption, efflux, transport, and excretion, amongst others. Beaven et al. (2011) found that LXR ligands suppressed the activation of primary mouse stellate cells and expression of fibrosis-related genes, leading such ligands to be considered new antifibrogenic factors (Mallat and Lotersztajn, 2011).

\section{ANIMAL MODELS OF NASH-RELATED FIBROGENESIS}

Dietary models of NASH include methionine-and cholinedeficient (MCD) diet, the F diet and atherogenic diets (Schattenberg and Galle, 2010). Mice or rats fed with a MCD diet develop hepatic steatosis, which then progresses into steatohepatitis, and eventually leads to pericellular fibrosis (George et al., 2003; Sahai et al., 2004). The MCD diet is the most commonly 


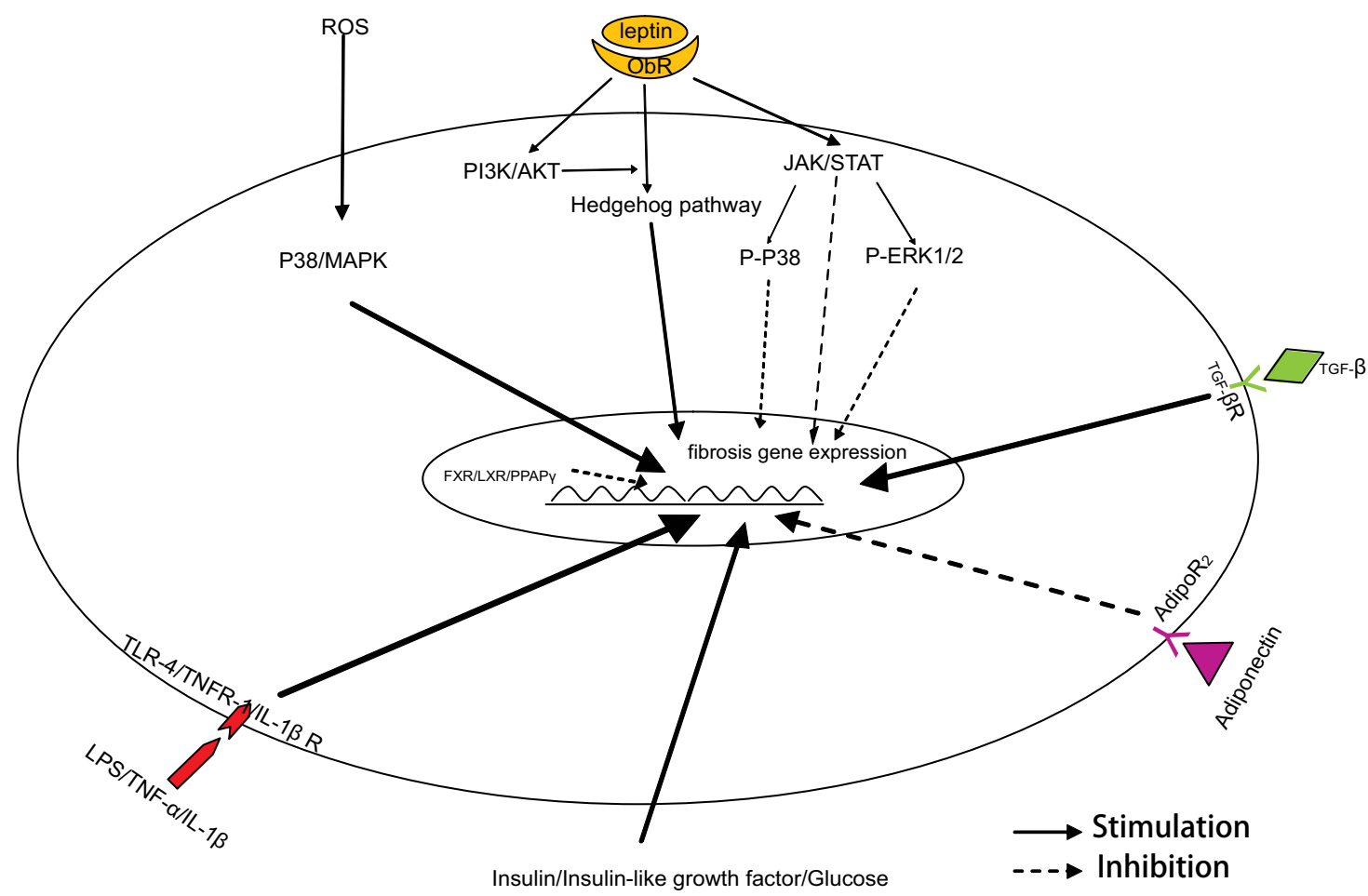

FIGURE 1 | Mechanism of HSC activation in NASH-related fibrogenesis.

used animal model to study pathogenesis of NASH-related fibrogenesis. However, the pathogenesis of fibrosis in mice fed with the MCD diet, including weight loss, increased peripheral insulin sensitivity, and loss of white adipose tissue are not characteristic of NASH-related fibrogenesis in human beings (Rinella and Green, 2004; Leclercq et al., 2007). Mice fed with a CDAA diet, display a similar liver phenotype to mice fed a MCD diet, but without weight loss, which suggests that this may be a better model (Kodama et al., 2009). Although a HF-diet increases metabolic risk factors in mice or rats, such as obesity, glucose intolerance, and increased lipogenic transcription factors, it rarely progress into liver fibrosis; however, $46 \%$ of mice overfed with a HF-diet (using an intragastric feeding protocol), developed steatohepatitis, and sinusoidal and pericellular fibrosis (Deng et al., 2005), although the high mortality rate and requirement for technical expertise means that the application of this model is limited.

Genetic models of NAFLD, including ob/ob mice, $\mathrm{db} / \mathrm{db}$ mice, fa/fa mice, $K K-A y / a$ mice, do not develop liver fibrosis, except for mice that overexpress of SREBP-1c (Halaas et al., 1995; Nakayama et al., 2007; Schattenberg and Galle, 2010). Recently, Ota et al. reported a combination of a genetic and feeding model, called the Otsuka Long-Evans Tokishima Fatty (OLETF) rat. When such rats

\section{REFERENCES}

Adler, M., Taylor, S., Okebugwu, K., Yee, H., Fielding, C., Fielding, G., and Poles, M. (2011). Intrahepatic natural killer $\mathrm{T}$ cell populations are increased in human hepatic steatosis. World J. Gastroenterol. 17, 1725-1731.

Aithal, G. P., Thomas, J. A., Kaye, P. V., Lawson, A., Ryder, S. D.,

is fed with a MCD diet or a fat-enriched MCD diet, they progress to severe liver fibrosis (Ota et al., 2007).

\section{CONCLUSION}

NASH currently represents one of the most prevalent liver diseases in humans, which is secondary to the increasing prevalence of obesity and the metabolic syndrome. It is well-known that the activation of HSCs is one of the critical events in NASH-related fibrogenesis. Insulin resistance, oxidative stress, pro-inflammatory cytokines, adipokines, and the innate immune response are involved in the phenotypic transition of HSCs (Figure 1), which then results in the development of NASH-related hepatic fibrogenesis. Of course, there are other factors we not mentioned here, such as endocannabinoid system and renin-angiotensin-aldosterone system. Because they are not as characteristic as insulin resistance and oxidative stress in NASH, although they play roles in NASHrelated fibrogenesis. All these factors may interact with each other, and form a unique network that leads to the pathogenesis of liver fibrosis. Combined treatments targeted to these different factors are a feasible strategy in NASH-related liver fibrosis. In addition, an ideal animal model of NASH will help us to characterize the mechanisms of liver fibrosis in metabolic syndrome and to identify novel therapeutic approaches in the treatment of liver fibrosis.

Spendlove, I., Austin, A. S., Freeman, J. G., Morgan, L., and Webber, J. (2008). Randomized, placebo-controlled trial of pioglitazone in nondiabetic subjects with nonalcoholic steatohepatitis. Gastroenterology 135, 1176-1184.

Asano, T., Watanabe, K., Kubota, N., Gunji, T., Omata, M., Kadowaki, T., and Ohnishi, S. (2009). Adiponectin 
knockout mice on high fat diet develop fibrosing steatohepatitis. J. Gastroenterol. Hepatol. 24, 1669-1676.

Bataller, R., Sancho-Bru, P., Gines, P., and Brenner, D. A. (2005). Liver fibrogenesis: a new role for the reninangiotensin system. Antioxid. Redox Signal. 7, 1346-1355.

Beaven, S. W., Wroblewski, K., Wang, J., Hong, C., Bensinger, S., Tsukamoto, H., and Tontonoz, P. (2011). Liver $\mathrm{X}$ receptor signaling is a determinant of stellate cell activation and susceptibility to fibrotic liver disease. Gastroenterology 140, 1052-1062.

Belfort, R., Harrison, S. A., Brown, K., Darland, C., Finch, J., Hardies, J., Balas, B., Gastaldelli, A., Tio, F., Pulcini, J., Berria, R., Ma, J. Z., Dwivedi, S., Havranek, R., Fincke, C., DeFronzo, R., Bannayan, G. A., Schenker, S., and Cusi, K. (2006). A placebo-controlled trial of pioglitazone in subjects with nonalcoholic steatohepatitis. N. Engl. J. Med. 355, 2297-2307.

Bloom, S. R., Kuhajda, F. P., Laher, I., Pi-Sunyer, X., Ronnett, G. V., Tan, T. M., and Weigle, D. S. (2008). The obesity epidemic: pharmacological challenges. Mol. Interv. 8, 82-98.

Brun, P., Castagliuolo, I., Pinzani, M., Palu, G., and Martines, D. (2005). Exposure to bacterial cell wall products triggers an inflammatory phenotype in hepatic stellate cells. Am. J. Physiol. Gastrointest. Liver Physiol. 289, G571-G578.

Brunt, E. M. (2004). Nonalcoholic steatohepatitis. Semin. Liver Dis. 24, 3-20.

Bugianesi, E., Manzini, P., D'Antico, S., Vanni, E., Longo, F., Leone, N., Massarenti, P., and Rizzetto, M. (2004). Relative contribution of iron burden, HFE mutations, and insulin resistance to fibrosis in nonalcoholic fatty liver. Hepatology 39, 179-187.

Cao, Q., Mak, K. M., and Lieber, C. S. (2007). Leptin represses matrix metalloproteinase-1 gene expression in LX2 human hepatic stellate cells. J. Hepatol. 46, 124-133.

Chalasani, N., Deeg, M. A., and Crabb, D. W. (2004). Systemic levels of lipid peroxidation and its metabolic and dietary correlates in patients with nonalcoholic steatohepatitis. Am. J. Gastroenterol. 99, 1497-1502.

Chitturi, S., Abeygunasekera, S., Farrell, G. C., Holmes-Walker, J., Hui, J. M., Fung, C., Karim, R., Lin, R., Samarasinghe, D., Liddle, C., Weltman, M., and George, J. (2002). $\mathrm{NASH}$ and insulin resistance: insulin hypersecretion and specific association with the insulin resistance syndrome. Hepatology 35, 373-379.

Choi, S. S., Syn, W. K., Karaca, G. F., Omenetti, A., Moylan, C. A., Witek, R. P., Agboola, K. M., Jung, Y., Michelotti, G. A., and Diehl, A. M. (2010). Leptin promotes the myofibroblastic phenotype in hepatic stellate cells by activating the hedgehog pathway. $J$. Biol. Chem. 285, 36551-36560.

Cohen, J. C., Horton, J. D., and Hobbs, H. H. (2011). Human fatty liver disease: old questions and new insights. Science 332, 1519-1523.

Cressman, D. E., Greenbaum, L. E., DeAngelis, R. A., Ciliberto, G., Furth, E. E., Poli, V., and Taub, R. (1996). Liver failure and defective hepatocyte regeneration in interleukin-6-deficient mice. Science 274, 1379-1383.

Day, C. P., and James, O. F. (1998). Steatohepatitis: a tale of two "hits?" Gastroenterology 114, 842-845.

De Minicis, S., Bataller, R., and Brenner, D. A. (2006). NADPH oxidase in the liver: defensive, offensive, or fibrogenic? Gastroenterology 131, 272-275.

De Minicis, S., Seki, E., Paik, Y. H., Osterreicher, C. H., Kodama, Y., Kluwe, J., Torozzi, L., Miyai, K., Benedetti, A., Schwabe, R. F., and Brenner, D. A. (2010). Role and cellular source of nicotinamide adenine dinucleotide phosphate oxidase in hepatic fibrosis. Hepatology 52, 1420-1430.

De Minicis, S., and Svegliati-Baroni, G. (2011). Fibrogenesis in nonalcoholic steatohepatitis. Expert Rev. Gastroenterol. Hepatol. 5, 179-187.

de Oliveira, C. P., Stefano, J. T., de Siqueira, E. R., Silva, L. S., de Campos Mazo, D. F., Lima, V. M., Furuya, C. K., Mello, E. S., Souza, F. G., Rabello, F., Santos, T. E., Nogueira, M. A., Caldwell, S. H., Alves, V. A., and Carrilho, F. J. (2008). Combination of $\mathrm{N}$-acetylcysteine and metformin improves histological steatosis and fibrosis in patients with non-alcoholic steatohepatitis. Hepatol. Res. 38, 159-165.

Deng, Q. G., She, H., Cheng, J. H., French, S. W., Koop, D. R., Xiong, S., and Tsukamoto, H. (2005). Steatohepatitis induced by intragastric overfeeding in mice. Hepatology 42, 905-914.

Deng, Z. B., Liu, Y., Liu, C., Xiang, X., Wang, J., Cheng, Z., Shah, S. V., Zhang, S., Zhang, L., Zhuang, X., Michalek, S., Grizzle, W. E., and Zhang, H. G. (2009). Immature myeloid cells induced by a high-fat diet contribute to liver inflammation. Hepatology 50, 1412-1420.
El-Assal, O., Hong, F., Kim, W. H., Radaeva, S., and Gao, B. (2004). IL-6-deficient mice are susceptible to ethanol-induced hepatic steatosis: IL-6 protects against ethanolinduced oxidative stress and mitochondrial permeability transition in the liver. Cell. Mol. Immunol. 1, 205-211.

Elinav, E., Pappo, O., Sklair-Levy, M., Margalit, M., Shibolet, O., Gomori, M., Alper, R., Thalenfeld, B., Engelhardt, D., Rabbani, E., and Ilan, Y. (2006). Amelioration of nonalcoholic steatohepatitis and glucose intolerance in ob/ob mice by oral immune regulation towards liverextracted proteins is associated with elevated intrahepatic NKT lymphocytes and serum IL-10 levels. J. Pathol. 208, 74-81.

Farrell, G. C., and Larter, C. Z. (2006). Nonalcoholic fatty liver disease: from steatosis to cirrhosis. Hepatology 43, S99-S112.

Fiorucci, S., Antonelli, E., Rizzo, G. Renga, B., Mencarelli, A., Riccardi, L., Orlandi, S., Pellicciari, R., and Morelli, A. (2004). The nuclear receptor SHP mediates inhibition of hepatic stellate cells by FXR and protects against liver fibrosis. Gastroenterology 127, 1497-1512.

Fracanzani, A. L., Valenti, L., Bugianesi, E., Andreoletti, M., Colli, A., Vanni, E., Bertelli, C., Marchesini, G., and Fargion, S. (2008). Risk of severe liver disease in nonalcoholic fatty liver disease with normal aminotransferase levels: a role for insulin resistance and diabetes. Hepatology 48, 792-798.

Gastaldelli, A., Harrison, S., BelfortAguiar, R., Hardies, J., Balas, B., Schenker, S., and Cusi, K. (2010) Pioglitazone in the treatment of NASH: the role of adiponectin. Aliment. Pharmacol. Ther. 32, 769-775.

George, J., Pera, N., Phung, N., Leclercq, I., Yun Hou, J., and Farrell, G. (2003). Lipid peroxidation, stellate cell activation and hepatic fibrogenesis in a rat model of chronic steatohepatitis. J. Hepatol. 39, 756-764.

Guimaraes, E. L., Franceschi, M. F. Grivicich, I., Dal-Pizzol, F., Moreira, J. C., Guaragna, R. M., Borojevic, R., Margis, R., and Guma, F. C. (2006). Relationship between oxidative stress levels and activation state on a hepatic stellate cell line. Liver Int. 26, 477-485.

Halaas, J. L., Gajiwala, K. S., Maffei, M., Cohen, S. L., Chait, B. T., Rabinowitz, D., Lallone, R. L., Burley, S. K., and Friedman, J. M. (1995). Weight-reducing effects of the plasma protein encoded by the obese gene. Science 269, 543-546.

Hegde, S., Fox, L., Wang, X., and Gumperz, J. E. (2010). Autoreactive natural killer $\mathrm{T}$ cells: promoting immune protection and immune tolerance through varied interactions with myeloid antigenpresenting cells. Immunology 130, 471-483.

Ikeda, R., Ishii, K., Hoshikawa, Y., Azumi, J., Arakaki, Y., Yasui, T., Matsuura, S., Matsumi, Y., Kono, Y., Mizuta, Y., Kurimasa, A., Hisatome, I., Friedman, S. L., Kawasaki, H., and Shiota, G. (2011). Reactive oxygen species and NADPH oxidase 4 induced by transforming growth factor betal are the therapeutic targets of polyenylphosphatidylcholine in the suppression of human hepatic stellate cell activation. Inflamm. Res. 60, 597-604.

Ishikawa, S., Ikejima, K., Yamagata, H., Aoyama, T., Kon, K., Arai, K., Takeda, K., and Watanabe, S. (2011). CD1drestricted natural killer $\mathrm{T}$ cells contribute to hepatic inflammation and fibrogenesis in mice. J. Hepatol. 54, 1195-1204.

Jin, X., Zimmers, T. A., Perez, E. A., Pierce, R. H., Zhang, Z., and Koniaris, L. G. (2006). Paradoxical effects of short- and longterm interleukin-6 exposure on liver injury and repair. Hepatology 43, 474-484.

Jou, J., Choi, S. S., and Diehl, A. M. (2008). Mechanisms of disease progression in nonalcoholic fatty liver disease. Semin. Liver Dis. 28, 370-379.

Kaji, K., Yoshiji, H., Kitade, M., Ikenaka, Y., Noguchi, R., Shirai, Y., Aihara, Y., Namisaki, T., Yoshii, J., Yanase, K., Tsujimoto, T., Kawaratani, H., and Fukui, H. (2011). Combination treatment of angiotensin II type I receptor blocker and new oral iron chelator attenuates progression of nonalcoholic steatohepatitis in rats. Am. J. Physiol. Gastrointest. Liver Physiol. 300, G1094-G1104.

Kamada, Y., Matsumoto, H., Tamura, S., Fukushima, J., Kiso, S., Fukui, K., Igura, T., Maeda, N., Kihara, S., Funahashi, T., Matsuzawa, Y., Shimomura, I., and Hayashi, N. (2007). Hypoadiponectinemia accelerates hepatic tumor formation in a nonalcoholic steatohepatitis mouse model. J. Hepatol. 47, 556-564.

Kamada, Y., Tamura, S., Kiso, S., Matsumoto, H., Saji, Y., Yoshida, Y., Fukui, K., Maeda, N., Nishizawa, H., Nagaretani, H., Okamoto, Y., Kihara, S., Miyagawa, J., Shinomura, Y., Funahashi, T., and 
Matsuzawa, Y. (2003). Enhanced carbon tetrachloride-induced liver fibrosis in mice lacking adiponectin. Gastroenterology 125, 1796-1807.

Kim, H. J., Higashimori, T., Park, S. Y., Choi, H., Dong, J., Kim, Y. J., Noh, H. L., Cho, Y. R., Cline, G., Kim, Y. B., and Kim, J. K. (2004). Differential effects of interleukin-6 and -10 on skeletal muscle and liver insulin action in vivo. Diabetes 53, 1060-1067.

Kleiner, D. E., Brunt, E. M., Van Natta, M., Behling, C., Contos, M. J., Cummings, O. W., Ferrell, L. D., Liu, Y. C., Torbenson, M. S., Unalp-Arida, A., Yeh, M., McCullough, A. J., Sanyal, A. J., and Nonalcoholic Steatohepatitis Clinical Research Network. (2005). Design and validation of a histological scoring system for nonalcoholic fatty liver disease. Hepatology 41, 1313-1321.

Kodama, Y., Kisseleva, T., Iwaisako, K., Miura, K., Taura, K., De Minicis, S., Osterreicher, C. H., Schnabl, B., Seki, E., and Brenner, D. A. (2009). c-Jun N-terminal kinase1 from hematopoietic cells mediates progression from hepatic steatosis to steatohepatitis and fibrosis in mice. Gastroenterology 137, 1467-1477 e1465.

Koek, G. H., Liedorp, P. R., and Bast, A. (2011). The role of oxidative stress in non-alcoholic steatohepatitis. Clin. Chim. Acta 412, 1297-1305.

Krawczyk, M., Bonfrate, L., and Portincasa, P. (2010). Nonalcoholic fatty liver disease. Best Pract. Res. Clin. Gastroenterol. 24, 695-708.

Kremer, M., Thomas, E., Milton, R. J., Perry, A. W., van Rooijen, N., Wheeler, M. D., Zacks, S., Fried, M., Rippe, R. A., and Hines, I. N. (2010). Kupffer cell and interleukin12-dependent loss of natural killer T cells in hepatosteatosis. Hepatology $51,130-141$

Kukla, M., Ciupinska-Kajor, M., Kajor, M., Wylezol, M., Zwirska-Korczala, K., Hartleb, M., Berdowska, A., and Mazur, W. (2010a). Liver visfatin expression in morbidly obese patients with nonalcoholic fatty liver disease undergoing bariatric surgery. Pol. J. Pathol. 61, 147-153.

Kukla, M., Zwirska-Korczala, K., Hartleb, M., Waluga, M., Chwist, A., Kajor, M., Ciupinska-Kajor, M., Berdowska, A., Wozniak-Grygiel, E., and Buldak, R. (2010b). Serum chemerin and vaspin in nonalcoholic fatty liver disease. Scand. J. Gastroenterol. 45, 235-242.

Kukla, M., Mazur, W., Buldak, R. J., and Zwirska-Korczala, K. (2011). Potential role of leptin, adiponectin and the novel adipokines-visfatin, chemerin and vaspin-in chronic hepatitis. Mol. Med. 17, 1397-1410.

Law, K., and Brunt, E. M. (2010). Nonalcoholic fatty liver disease. Clin. Liver Dis. 14, 591-604.

Leclercq, I. A., Lebrun, V. A., Starkel, P., and Horsmans, Y. J. (2007). Intrahepatic insulin resistance in a murine model of steatohepatitis: effect of PPARgamma agonist pioglitazone. Lab. Invest. 87, 56-65.

Lemoine, M., Ratziu, V., Kim, M., Maachi, M., Wendum, D., Paye, F., Bastard, J. P., Poupon, R., Housset, C., Capeau, J., and Serfaty, L. (2009). Serum adipokine levels predictive of liver injury in nonalcoholic fatty liver disease. Liver Int. 29, 1431-1438.

Li, J., Fan, R., Zhao, S., Liu, L., Guo, S., Wu, N., Zhang, W., and Chen, P. (2011). Reactive oxygen species released from hypoxic hepatocytes regulates MMP-2 expression in hepatic stellate cells. Int. J. Mol. Sci. 12, 2434-2447.

Li, J., Kuruba, R., Wilson, A., Gao, X., Zhang, Y., and Li, S. (2010). Inhibition of endothelin-1-mediated contraction of hepatic stellate cells by FXR ligand. PLoS ONE 5, el3955. doi:10.1371/journal.pone.0013955

Li, Z., Soloski, M. J., and Diehl, A. M. (2005). Dietary factors alter hepatic innate immune system in mice with nonalcoholic fatty liver disease. Hepatology 42, 880-885.

Mallat, A., and Lotersztajn, S. (2011). The liver X receptor in hepatic stellate cells: a novel antifibrogenic target? J. Hepatol. 55, 1452-1454.

Marra, F., Aleffi, S., Bertolani, C., Petrai, I., and Vizzutti, F. (2005). Review article: the pathogenesis of fibrosis in non-alcoholic steatohepatitis. Aliment. Pharmacol. Ther. 22(Suppl. 2), 44-47.

Marra, F., and Bertolani, C. (2009). Adipokines in liver diseases. Hepatology 50, 957-969.

Marra, F., Navari, N., Vivoli, E., Galastri, S., and Provenzano, A. (2011). Modulation of liver fibrosis by adipokines. Dig. Dis. 29, 371-376.

Matsunami, T., Sato, Y., Ariga, S., Sato, T., Kashimura, H., Hasegawa, Y., and Yukawa, M. (2010). Regulation of oxidative stress and inflammation by hepatic adiponectin receptor 2 in an animal model of nonalcoholic steatohepatitis. Int. J. Clin. Exp. Pathol. 3, 472-481.

McCarty, M. F. (2011). Full-spectrum antioxidant therapy featuring astaxanthin coupled with lipoprivic strategies and salsalate for management of non-alcoholic fatty liver disease. Med. Hypotheses 77, 550-556.

Medici, V., Ali, M. R., Seo, S., Aoki, C. A., Rossaro, L., Kim, K., Fuller W. D., Vidovszky, T. J., Smith, W. Jiang, J. X., Maganti, K., Havel, P. J., Kamboj, A., Ramsamooj, R., and Török, N. J. (2010). Increased soluble leptin receptor levels in morbidly obese patients with insulin resistance and nonalcoholic fatty liver disease. Obesity (Silver Spring) 18, 2268-2273.

Miura, K., Kodama, Y., Inokuchi, S., Schnabl, B., Aoyama, T., Ohnishi, H., Olefsky, J. M., Brenner, D. A., and Seki, E. (2010). Toll-like receptor 9 promotes steatohepatitis by induction of interleukin1beta in mice. Gastroenterology 139, 323-334 e327.

Nakagami, H., Shimamura, M., Miyake, T., Shimosato, T., Minobe, N., Moritani, T., Kiomy Osako, M., Nakagami, F., Koriyama, H., Kyutoku, M., Shimizu, H., Katsuya, T., and Morishita, R. (2012). Nifedipine prevents hepatic fibrosis in a nonalcoholic steatohepatitis. Mol. Med. Report 5, 37-40.

Nakayama, H., Otabe, S., Ueno, T., Hirota, N., Yuan, X., Fukutani, T., Hashinaga, T., Wada, N., and Yamada, K. (2007). Transgenic mice expressing nuclear sterol regulatory element-binding protein $1 \mathrm{c}$ in adipose tissue exhibit liver histology similar to nonalcoholic steatohepatitis. Metab. Clin. Exp. 56, 470-475.

Ota, T., Takamura, T., Kurita, S., Matsuzawa, N., Kita, Y., Uno, M., Akahori, H., Misu, H., Sakurai, M., Zen, Y., Nakanuma, Y., and Kaneko, S. (2007). Insulin resistance accelerates a dietary rat model of nonalcoholic steatohepatitis. Gastroenterology 132, 282-293.

Paradis, V., Perlemuter, G., Bonvoust, F., Dargere, D., Parfait, B., Vidaud, M., Conti, M., Huet, S., Ba, N., Buffet, C., and Bedossa, P. (2001). High glucose and hyperinsulinemia stimulate connective tissue growth factor expression: a potential mechanism involved in progression to fibrosis in nonalcoholic steatohepatitis. Hepatology 34, 738-744.

Pinzani, M. (2011). Pathophysiology of non-alcoholic steatohepatitis and basis for treatment. Dig. Dis. 29, 243-248.

Polyzos, S. A., Kountouras, J., Zavos, C., and Tsiaousi, E. (2010). The role of adiponectin in the pathogenesis and treatment of non-alcoholic fatty liver disease. Diabetes Obes. Metab. 12, 365-383.
Promrat, K., Lutchman, G., Uwaifo, G. I., Freedman, R. J., Soza, A., Heller T., Doo, E., Ghany, M., Premkumar, A., Park, Y., Liang, T. J., Yanovski, J. A., Kleiner, D. E., and Hoofnagle, J. H. (2004). A pilot study of pioglitazone treatment for nonalcoholic steatohepatitis. Hepatology 39, 188-196.

Ratziu, V., Charlotte, F., Bernhardt, C., Giral, P., Halbron, M., Lenaour, G., Hartmann-Heurtier, A., Bruckert, E., Poynard, T., and LIDO Study Group. (2010). Long-term efficacy of rosiglitazone in nonalcoholic steatohepatitis: results of the fatty liver improvement by rosiglitazone therapy (FLIRT 2) extension trial. Hepatology 51, 445-453.

Ratziu, V., Giral, P., Jacqueminet, S., Charlotte, F., Hartemann-Heurtier, A., Serfaty, L., Podevin, P., Lacorte, J. M., Bernhardt, C., Bruckert, E., Grimaldi, A., Poynard, T., and LIDO Study Group. (2008). Rosiglitazone for nonalcoholic steatohepatitis: one-year results of the randomized placebo-controlled fatty liver improvement with rosiglitazone therapy (FLIRT) trial. Gastroenterology 135, 100-110.

Renga, B., Mencarelli, A., Migliorati, M., Cipriani, S., D’Amore, C., Distrutti, E., and Fiorucci, S. (2011). SHP-dependent and -independent induction of peroxisome proliferator-activated receptor-gamma by the bile acid sensor farnesoid X receptor counterregulates the pro-inflammatory phenotype of liver myofibroblasts. Inflamm. Res. 60, 577-587.

Rinella, M. E., and Green, R. M. (2004). The methionine-choline deficient dietary model of steatohepatitis does not exhibit insulin resistance. $J$. Hepatol. 40, 47-51.

Rombouts, K., and Marra, F. (2010). Molecular mechanisms of hepatic fibrosis in non-alcoholic steatohepatitis. Dig. Dis. 28, 229-235.

Sahai, A., Malladi, P., Melin-Aldana, H., Green, R. M., and Whitington, P. F. (2004). Upregulation of osteopontin expression is involved in the development of nonalcoholic steatohepatitis in a dietary murine model. Am. J. Physiol. Gastrointest. Liver Physiol. 287, G264-G273.

Salman, T. A., Allam, N., Azab, G. I., Shaarawy, A. A., Hassouna, M. M., and El-Haddad, O. M. (2010). Study of adiponectin in chronic liver disease and cholestasis. Hepatol. Int. 4 , 767-774.

Sanyal, A. J., Mofrad, P. S., Contos, M. J., Sargeant, C., Luketic, V. A., Sterling, R. K., Stravitz, R. T., Shiffman, M. L., 
Clore, J., and Mills, A. S. (2004). A pilot study of vitamin E versus vitamin $\mathrm{E}$ and pioglitazone for the treatment of nonalcoholic steatohepatitis. Clin. Gastroenterol. Hepatol. 2, 1107-1115.

Schattenberg, J. M., and Galle, P. R. (2010). Animal models of nonalcoholic steatohepatitis: of mice and man. Dig. Dis. 28, 247-254.

Seki, E., De Minicis, S., Osterreicher, C. H., Kluwe, J., Osawa, Y., Brenner, D. A., and Schwabe, R. F. (2007). TLR4 enhances TGF-beta signaling and hepatic fibrosis. Nat. Med. 13, 1324-1332.

Sell, H., Divoux, A., Poitou, C., Basdevant, A., Bouillot, J. L., Bedossa, P., Tordjman, J., Eckel, J., and Clément, K. (2010). Chemerin correlates with markers for fatty liver in morbidly obese patients and strongly decreases after weight loss induced by bariatric surgery. J. Clin. Endocrinol. Metab. 95, 2892-2896.

Syn, W. K., Oo, Y. H., Pereira, T. A., Karaca, G. F., Jung, Y., Omenetti, A., Witek, R. P., Choi, S. S., Guy, C. D., Fearing, C. M., Teaberry, V., Pereira, F. E., Adams, D. H., and Diehl, A. M. (2010). Accumulation of natural killer $\mathrm{T}$ cells in progressive nonalcoholic fatty liver disease. Hepatology 51, 1998-2007.

Tajiri, K., Shimizu, Y., Tsuneyama, K., and Sugiyama, T. (2009). Role of liver-infiltrating CD3+CD56+ natural killer $\mathrm{T}$ cells in the pathogenesis of nonalcoholic fatty liver disease. Eur. J. Gastroenterol. Hepatol. 21, 673-680.

Tarrats, N., Moles, A., Morales, A., Garcia-Ruiz, C., Fernandez-Checa, J. C., and Mari, M. (2011). Critical role of tumor necrosis factor receptor 1 , but not 2 , in hepatic stellate cell proliferation, extracellular matrix remodeling, and liver fibrogenesis. Hepatology 54, 319-327.

Tilg, H., and Moschen, A. R. (2010) Evolution of inflammation in nonalcoholic fatty liver disease: the multiple parallel hits hypothesis. Hepatology 52, 1836-1846.

Tsukada, S., Parsons, C. J., and Rippe, R. A. (2006). Mechanisms of liver fibrosis. Clin. Chim. Acta 364, 33-60.

Urtasun, R., Conde de la Rosa, L., and Nieto, N. (2008). Oxidative and nitrosative stress and fibrogenic response. Clin. Liver Dis. 12, 769-790.

Uygun, A., Kadayifci, A., Yesilova, Z., Erdil, A., Yaman, H., Saka, M., Deveci, M. S., Bagci, S., Gulsen, M., Karaeren, N., and Dagalp, K. (2000). Serum leptin levels in patients with nonalcoholic steatohepatitis. Am. J. Gastroenterol. 95, 3584-3589.

Vera, M., and Nieto, N. (2006). Hepatic stellate cells and alcoholic liver disease. Rev. Esp. Enferm. Dig. 98, 674-684.

Wagner, M., Zollner, G., and Trauner, M. (2011). Nuclear receptors in liver disease. Hepatology 53, 1023-1034.

Watanabe, A., Hashmi, A., Gomes, D. A., Town, T., Badou, A., Flavell, R. A., and Mehal, W. Z. (2007) Apoptotic hepatocyte DNA inhibits hepatic stellate cell chemotaxis via toll-like receptor 9. Hepatology 46, 1509-1518.

Williams, C. D., Stengel, J., Asike, M I., Torres, D. M., Shaw, J., Contreras, M., Landt, C. L., and Harrison, S. A. (2011). Prevalence of nonalcoholic fatty liver disease and nonalcoholic steatohepatitis among a largely middle-aged population utilizing ultrasound and liver biopsy: a prospective study. Gastroenterology 140, 124-131.

Yilmaz, Y., Kurt, R., Gurdal, A., Alahdab, Y. O., Yonal, O., Senates, E., Polat, N., Eren, F., Imeryuz, N., and Oflaz, H. (2011a). Circulating vaspin levels and epicardial adipose tissue thickness are associated with impaired coronary flow reserve in patients with nonalcoholic fatty liver disease. Atherosclerosis 217, 125-129.

Yilmaz, Y., Yonal, O., Kurt, R., Alahdab, Y. O., Eren, F., Ozdogan, O., Celikel, C. A., Imeryuz, N., Kalayci, C., and Avsar, E. (2011b). Serum levels of omentin, chemerin and adipsin in patients with biopsy-proven nonalcoholic fatty liver disease. Scand. J. Gastroenterol. 46, 91-97.

Zhang, Y., Proenca, R., Maffei, M. Barone, M., Leopold, L., and Friedman, J. M. (1994). Positional cloning of the mouse obese gene and its human homologue. Nature 372, 425-432.

Conflict of Interest Statement: The authors declare that the research was conducted in the absence of any commercial or financial relationships that could be construed as a potential conflict of interest.

Received: 14 January 2012; accepted: 17 June 2012; published online: 11 July 2012.

Citation: Bian $Z$ and $M a X$ (2012) Liver fibrogenesis in non-alcoholic steatohepatitis. Front. Physio. 3:248. doi: 10.3389/fphys.2012.00248

This article was submitted to Frontiers in Gastrointestinal Sciences, a specialty of Frontiers in Physiology.

Copyright (c) 2012 Bian and Ma. This is an open-access article distributed under the terms of the Creative Commons Attribution License, which permits use, distribution and reproduction in other forums, provided the original authors and source are credited and subject to any copyright notices concerning any third-party graphics etc. 